\title{
Embryonic expression of priapulid Wnt genes
}

\author{
Mattias Hogvall $^{1}$ • Bruno C. Vellutini ${ }^{2,3}$ - José M. Martín-Durán ${ }^{2,4} \cdot$ Andreas Hejnol $^{2} \cdot$ Graham E. Budd $^{1}$. \\ Ralf Janssen ${ }^{1}(10$
}

Received: 20 February 2019 / Accepted: 2 June 2019 /Published online: 4 July 2019

(C) The Author(s) 2019

\begin{abstract}
Posterior elongation of the developing embryo is a common feature of animal development. One group of genes that is involved in posterior elongation is represented by the Wnt genes, secreted glycoprotein ligands that signal to specific receptors on neighbouring cells and thereby establish cell-to-cell communication. In segmented animals such as annelids and arthropods, Wnt signalling is also likely involved in segment border formation and regionalisation of the segments. Priapulids represent unsegmented worms that are distantly related to arthropods. Despite their interesting phylogenetic position and their importance for the understanding of ecdysozoan evolution, priapulids still represent a highly underinvestigated group of animals. Here, we study the embryonic expression patterns of the complete sets of Wnt genes in the priapulids Priapulus caudatus and Halicryptus spinulosus. We find that both priapulids possess a complete set of $12 \mathrm{Wnt}$ genes. At least in Priapulus, most of these genes are expressed in and around the posterior-located blastopore and thus likely play a role in posterior elongation. Together with previous work on the expression of other genetic factors such as caudal and even-skipped, this suggests that posterior elongation in priapulids is under control of the same (or very similar) conserved gene regulatory network as in arthropods.
\end{abstract}

Keywords Ecdysozoan ancestor $\cdot$ Wnt signalling $\cdot$ Evolution $\cdot$ Penis worm $\cdot$ Posterior elongation

\section{Introduction}

Wnt signalling is crucial for animal development, as it is involved in the regulation of numerous developmental processes such as cell proliferation and cell migration, organogenesis and pattern formation. Wnt genes encode secreted glycoprotein ligands that bind to various transmembrane receptors such as seven-pass Frizzled receptors and the receptor tyrosine kinases Ryk and Ror. Binding of Wnt(s) to their receptors induces intracellular gene cascades that lead (in the canonical Wnt pathway) to the release of beta-catenin which then regulates the transcription of Wnt target genes (reviewed in e.g. Logan and Nusse 2004, Croce and McClay 2008, Wiese et al. 2018). Wnt genes are subdivided into 13 classes, of which 12

Communicated by Nico Posnien

Electronic supplementary material The online version of this article (https://doi.org/10.1007/s00427-019-00636-6) contains supplementary material, which is available to authorized users.

Ralf Janssen

ralf.janssen@geo.uu.se

Mattias Hogvall

mattias.hogvall@geo.uu.se

Bruno C. Vellutini

vellutini@mpi-cbg.de

José M. Martín-Durán

chema.martin@qmul.ac.uk

Andreas Hejnol

andreas.hejnol@sars.uib.no
Graham E. Budd

graham.budd@pal.uu.se

1 Department of Earth Sciences, Palaeobiology, Uppsala University, Villavägen 16, Uppsala, Sweden

2 Sars International Centre for Marine Molecular Biology, University of Bergen, Thormøhlensgate 55, 5006 Bergen, Norway

3 Max Planck Institute of Molecular Cell Biology and Genetics, Pfotenhauerstraße 108, 01307 Dresden, Germany

4 Present address: School of Biological and Chemical Sciences, Queen Mary University of London, Mile End Road, London E1 4NS, UK 
are present in protostomian animals; the Wnt3-class was lost in the lineage leading to Protostomia (e.g. Kusserow et al. 2005; Cho et al. 2010; Janssen et al. 2010). One of the key functions of Wnt signalling is its general involvement in posterior growth in animals (e.g. Yazawa et al. 2009; McIntyre et al. 2013; Scimone et al. 2016; Kawai et al. 2016; Leclère et al. 2016). Hence, in "overtly segmented" animals, i.e. vertebrates, annelids and panarthropods, Wnt signalling is a key component of posterior segment addition (reviewed in Aulehla and Herrmann 2004, Murat et al. 2010, Cho et al. 2010, Janssen et al. 2010, Pruitt et al. 2014). While the specific gene regulatory networks (GRN) controlling posterior growth and segmentation can differ between different groups of animals, and in some cases even between closely related species of the same group, Wnt signalling seems to be always involved. However, the molecular interactions of Wnt signalling in posterior growth are far from being resolved. In many groups of animals, Wnt signalling appears to interact with other conserved posterior factors such as Even-skipped (Eve), Caudal (Cad) and Delta-Notch (Dl/N) signalling in the form of partially conserved GRNs (e.g. Chawengsaksophak et al. 2004; de Rosa et al. 2005; Shimizu et al. 2005; Chesebro et al. 2013; McGregor et al. 2009; Oberhofer et al. 2014). A fact that complicates the understanding of posterior Wnt signalling is that different combinations of Wnt genes (and other components such as Wnt receptors) are involved in posterior Wnt signalling where they play redundant and/or complementary function(s). In arthropods for example, several Wnt genes are frequently expressed in the posterior-located segment addition zone from where new segments are added to the growing embryo (e.g. Janssen et al. 2010; Hayden and Arthur 2014; Constantinou et al. 2016), and functional studies revealed that at least some of them (as well as other factors of Wnt signalling) likely fulfil combinatorial and/or redundant function(s) in posterior elongation and segmentation (e.g. Bolognesi et al. 2008; Beermann et al. 2011; Murat et al. 2010).

Another conserved function of Wnts is their role in morphological and molecular border formation (and maintenance) within the developing embryo. In the fly Drosophila melanogaster, other arthropods and even tardigrades and onychophorans, $w g$ is likely involved in maintaining (para-) segmental boundaries and defining each segment's polarity (Sanson 2001; Janssen et al. 2004; Gabriel and Goldstein 2007; Eriksson et al. 2009), and gene expression data on other Wnt genes suggest their involvement in intrasegmental patterning and segment border formation/maintenance (e.g. Janssen et al. 2010; Hogvall et al. 2014; Hayden and Arthur 2014; Constantinou et al. 2016).

Priapulids (penis worms) represent a group of unsegmented ecdysozoan animals closely related to kinorhynchs (mud dragons) and loriciferans (brush heads), which together comprise the Scalidophora (Schmidt-Rhaesa 1998, Nielsen 2012,
Borner et al. 2014, reviewed in Giribet and Edgecombe 2017). Scalidophorans represent a group of ecdysozoans that may represent the sister group to all other ecdysozoans including arthropods and their close relatives (Campbell et al. 2011; Borner et al. 2014; Laumer et al. 2015) (Fig. 1(A)). However, note that ecdysozoan phylogeny is still not fully resolved (reviewed in Giribet and Edgecombe 2017).

Here, we investigate the Wnt gene complement, the stagespecific embryonic expression profiles and the embryonic expression patterns of the complete set of Wnt genes in the priapulid worm Priapulus caudatus (Fig. 1(B)). Our data reveal that several Wnt genes are expressed in specific posterior patterns, strongly suggesting a conserved role of Wnt genes in posterior growth in members of this group of ecdysozoan animals. However, none of the investigated Wnt genes is expressed in a pattern that could possibly represent a molecular remnant of body segmentation, or border formation in general.

\section{Methods}

\section{Animal collection, fertilisation and embryo fixation}

Sexually mature specimens of Priapulus caudatus were collected from Gullmarsfjorden (Fiskebäckskil, Sweden) in the area between Lysekil and Fiskebäckskil close to the Sven Lovén Centre for Marine Infrastructure. Mud was collected with a ring dredge from depths between approximately 30 and $60 \mathrm{~m}$. Gonads of mature specimens were dissected and kept in filtered deep seawater (fDSW). The oocytes were then released by shaking the ovaries and after cleaning with fDSW; active sperm from several males was used for in vitro fertilisation. Fertilised eggs were kept in Petri dishes in filtered fDSWand incubated at a constant temperature of $10^{\circ} \mathrm{C}$. The eggs were washed daily with fresh fDSW to keep dishes free from overgrowth with bacteria, fungi and protozoans. Around 10 days after fertilisation, larvae hatched and these so-called hatching larvae then developed into the first lorica larvae after 1 week (Wennberg et al. 2009). Batches of embryos were collected of each developmental stage (defined as day after fertilisation (DAF)) for either RNA extraction or in situ hybridisation. These latter embryos were permeabilised prior to fixation with $0.05 \%$ thioglycolate, $0.01 \%$ pronase in fDSW for $45 \mathrm{~min}$ at $10{ }^{\circ} \mathrm{C}$. After several washes in fDSW, the embryos were fixed in $4 \%$ paraformaldehyde in fDSWfor $1 \mathrm{~h}$ at room temperature, followed by several washes in phosphatebuffered saline with $0.1 \%$ Tween-20 (PBST). Samples fixed for gene expression studies were dehydrated in 50\% methanol in PBST, washed once in $100 \%$ methanol and then stored in methanol at $-20^{\circ} \mathrm{C}$. Embryos used for RNA extraction and subsequent RT-PCRs were shock-frozen at $-80^{\circ} \mathrm{C}$ and stored until RNA was extracted. 
Fig. 1 (A) Simplified cladogram representing the phylogenetic relationships of different ecdysozoan groups (after Campbell et al. 2011). (B) Adult specimen of the priapulid worm Priapulus caudatus next to a centimetre scale bar. Note subdivision of the adult body into the anterior introvert, the trunk and the posterior caudal appendage

\section{Ecdysozoa}

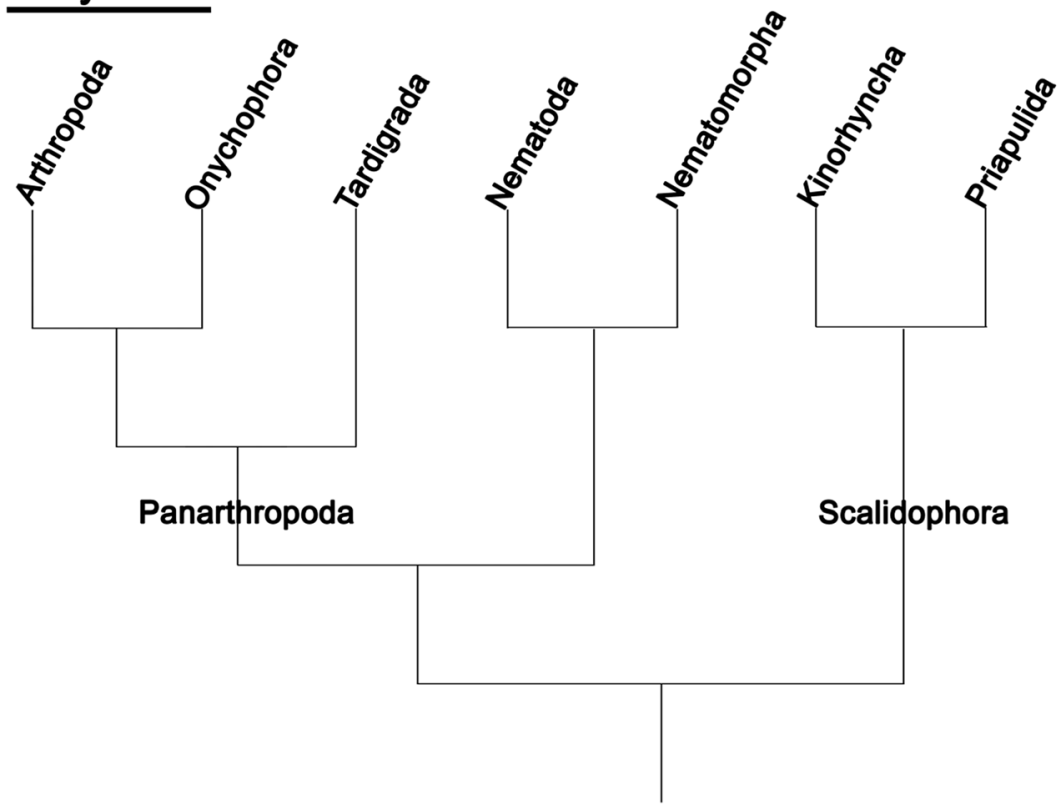

a

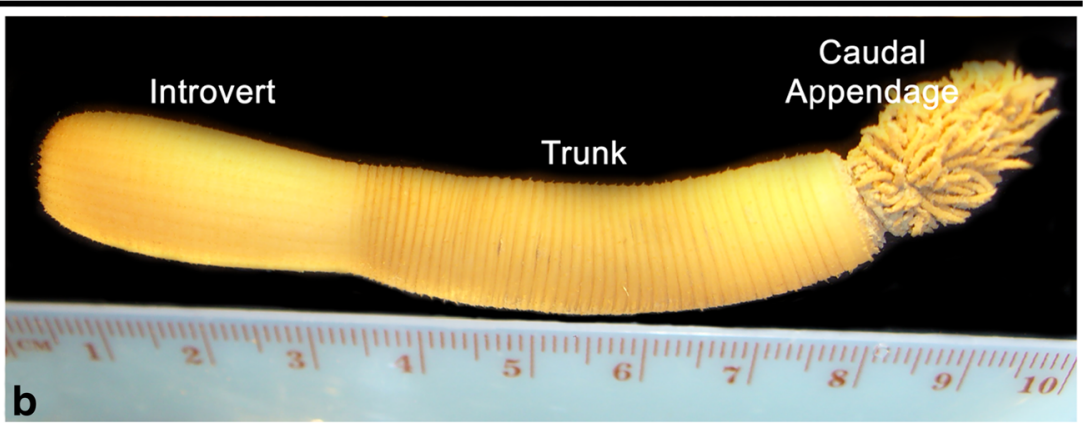

\section{Phylogenetic analysis}

Reciprocal BLAST search using Drosophila melanogaster wingless/Wnt 1 ( $w g / W n t 1)$ against sequenced transcriptomes of the priapulids Priapulus caudatus (SRX507009) and Halicryptus spinulosus (SRX1343820) identified 12 Wnt-like genes per species. Amino acid sequences of the Wnt genes from Priapulus, Halicryputs, various arthropods, the onychophoran Euperipatoides kanangrensis, the annelid Platynereis dumerilii and of Homo sapiens were aligned using T-Coffee followed by manual editing in SeaView (Notredame et al. 2000; Gouy et al. 2010) with default parameters in MacVector v12.6.0 (MacVector, Inc., Cary, NC). The phylogenetic analysis was conducted using MrBayes (Huelsenbeck and Ronquist 2001). A fixed WAG amino acid substitution model with gamma-distributed rate variation across sites (with four rate categories), unconstrained exponential prior probability distribution on branch lengths and exponential prior for the gamma shape parameters for among-site rate variation were applied. Gene topology was calculated using 13,000,000 cycles for the Metropolis-Coupled Markov Chain Monte Carlo (MCMCMC) analysis (four chains; chain-heating temperature of 0.2). Markov chains were sampled every 200 cycles and default settings of $25 \%$ of samples were applied as burn-in. Clade support was calculated with posterior probabilities in MrBayes.

\section{Stage-specific RNA-seq analyses}

Following the collection and fertilisation procedures above, we obtained bulk embryonic samples for a series of developmental stages that include oocytes and embryos at days 1, 3, 5, 7 and 9 post fertilisation. For this time course, we generated two biological replicates each coming from a common fertilisation using eggs from a single female individual and a sperm mix from different males. At least a thousand embryos were manually picked and transferred directly to RNAlater. We used TRIZOL (Invitrogen) to extract total RNA from each time point and sequenced single-end 50 base-pair reads of eleven samples using a single Illumina HiSeq2000 lane at the GeneCore (EMBL 
Genomics Core Facilities). One replicate of the 7-day sample failed at library preparation and was not included. We used kallisto (Bray et al. 2016) to quantify the transcript abundances by pseudoaligning the reads to a reference transcriptome (SRA Accession: SRX507009).

\section{Gene cloning and whole-mount in situ hybridisation}

Total RNA from a mix of developmental stages of Priapulus caudatus embryos and larvae was extracted using TRIZOL (Invitrogen). All investigated gene fragments were amplified by means of RT-PCR from total RNA that was reverse transcribed into cDNA. Gene-specific primers were designed based on available sequence information. For all genes, nested PCRs were conducted with internal primers, using a first PCR as template (see Supplementary Table 1 for primer sequence information). Amplified gene fragments were cloned into the PCRII vector (Invitrogen) and sequenced on an ABI3730XL automatic sequencer (Macrogen, Seoul, South Korea). Identification numbers are summarised in Supplementary Table 2 .

Single colorimetric in situ hybridisation was performed as described in Martín-Durán et al. (2012).

\section{Data documentation}

Prior to being photographed, embryos were incubated in $70 \%$ glycerol and mounted on glass slides under a thin glass cover. A Leica DFC550 digital camera mounted onto a Leica Leitz DMRXE dissection microscope was used. Whenever needed, contrast and brightness were adjusted using the imageprocessing software Adobe Photoshop CS6 for Apple Macintosh (Adobe Systems Inc.).

\section{Results}

\section{Sequence analysis}

Phylogenetic analysis confirms that the identified genes fall into the expected 12 classes of Wnt genes (Fig. 2(A)), showing that priapulids possess the full set of Wnt genes reported for protostomes (e.g. Janssen et al. 2010) (Fig. 2(B)). All priapulid Wnt genes (except Wnt16) cluster with absolute support (100\%) with confirmed Wnt orthologs from arthropods, an onychophoran (Euperipatoides kanangrensis), an annelid (Platynereis dumerilii) and human (Homo sapiens). Support for a monophyletic clade containing all Wnt16 orthologs is sufficiently high (81.5\%) to suggest that this represents a monophyletic group as well.

\section{Expression analysis based on stage-specific quantitative RNA sequencing}

We used stage-specific RNA-seq data from a time course including six different developmental stages (oocytes, 1 day after fertilisation (DAF), 3DAF, 5DAF, 7DAF, and 9DAF) to analyse the quantitative expression profile of Priapulus Wnt genes over time. Our data revealed that none of the Wnt genes is maternally expressed, and none of the Wnt genes is active early during development (1DAF) (Fig. 3). During gastrulation (3 DAF), however, all Wnt genes except for Wnt7, Wnt9, Wnt10 and Wnt11 are transcribed at a significant level (Fig. 3). At 5DAF, Wnt 10 appears to be transcribed (albeit at a significantly lower level than the other active Wnt genes). All nine active Wnt genes, Wnts 1, 2, 4, 5, 6, 8, 10, 16 and A, appear to be expressed at all subsequent developmental stages until the pre-hatching stage.

\section{Expression of Priapulus caudatus Wnt genes}

All priapulid Wnt genes for which we obtained reliable wholemount in situ hybridisation expression data are detected at the posterior pole of the developing embryo, close to, in or around the blastopore (cf. expression of $w g / W n t 1$ in the blastopore (Martín-Durán and Hejnol 2015)). We obtained data for late gastrula-stage embryos and so-called introvertula-stage embryos. The latter embryos are characterised by the formation of a groove that separates the posterior trunk from the anterior introvert (proboscis). Note that some embryos are slightly malformed as a result of the fixation procedure.

Wnt4 is expressed in the form of two domains, each on either side of the blastoporal region (Fig. 4(A, B)). Since determination of orientation of the embryo with respect to the left-right (LR) and dorsal-ventral (DV) axes is not possible due to the lack of morphological markers, we cannot decipher whether the expression domains are lateral to either side of the blastopore, or ventral and dorsal to the blastopore (although

Fig. 2 (A) Phylogenetic analysis of Wnt genes. Bayesian analysis of Wnt amino acid sequences. Support of each node is given as posterior probability. Included species are as follows: Achaearanea (syn. Parasteatoda) tepidariorum (At), Acyrthosiphon pisum (Ap), Cupiennius salei (Cs), Daphnia pulex (Dp), Drosophila melanogaster $(\mathrm{Dm})$, Euperipatoides kanangrensis (Ek), Glomeris marginata $(\mathrm{Gm})$, Halicryptus spinulosus (Hspi), Homo sapiens (Hs), Lxodes scapularis (Is), Platynereis dumerilii (Pd), Priapulus caudatus (Pc) and Tribolium castaneum (Tc). (B) Wnt gene complement in arthropods, an onychophoran and priapulids. Grey boxes indicate lost Wnt subfamilies. Question marks in grey boxes indicate Wnts that have not been found in sequenced embryonic transcriptomes. Duplicated Wnts are represented by overlapping boxes. (E) Unpublished embryonic expression pattern (R. Janssen); E, published embryonic expression pattern; e, embryonic expression has been investigated but specific expression patterns were not detected; F, functional data are available 


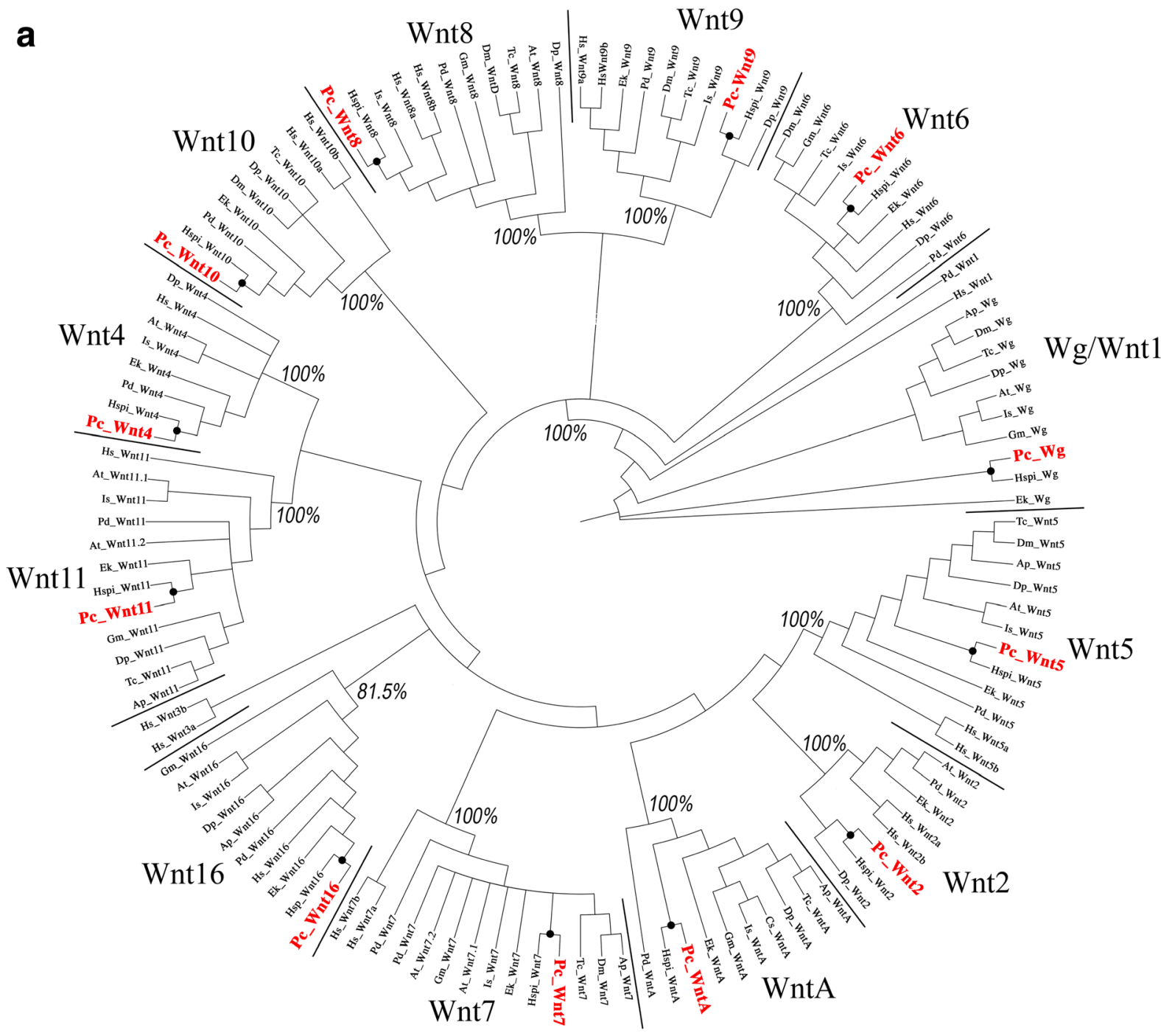

b

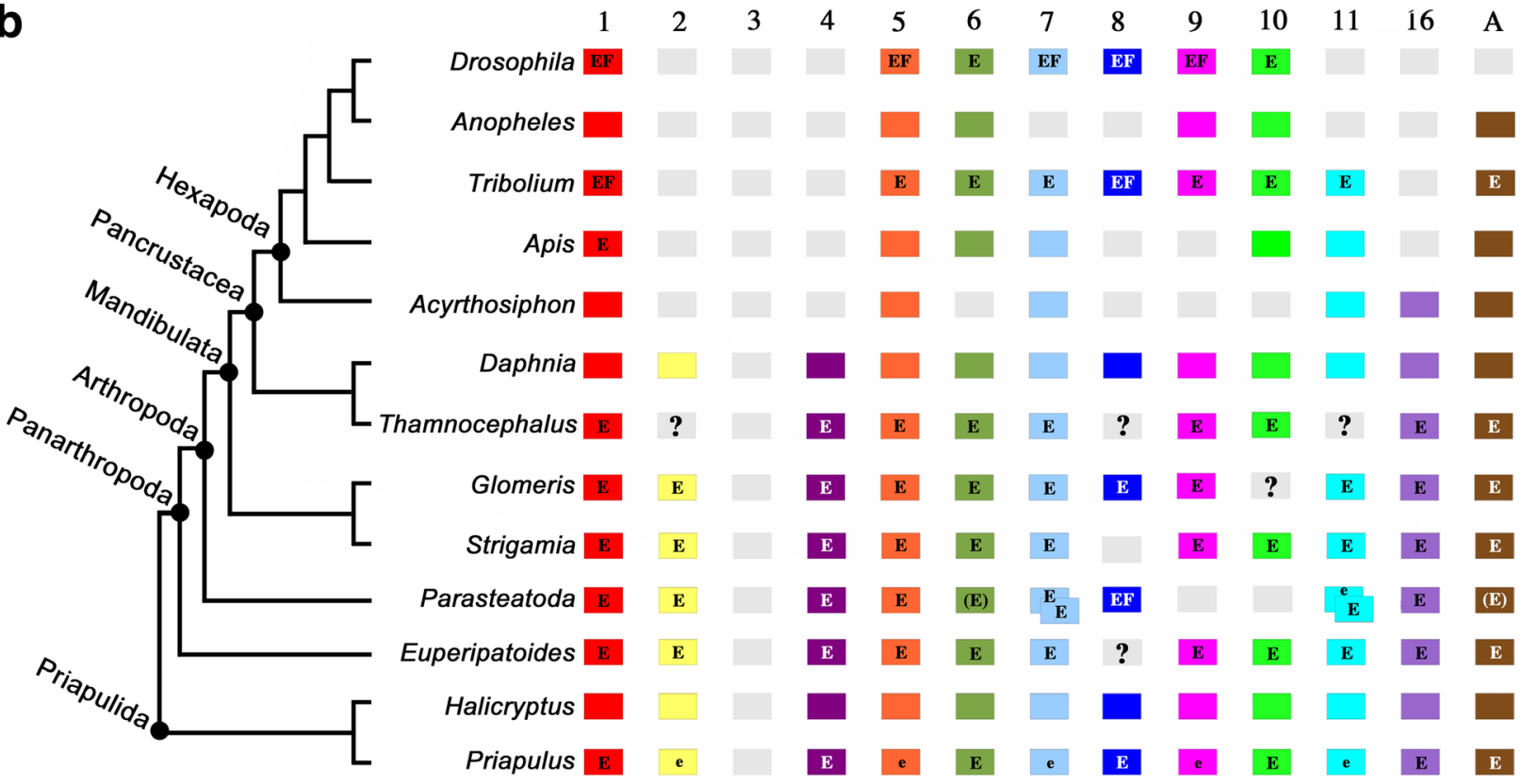




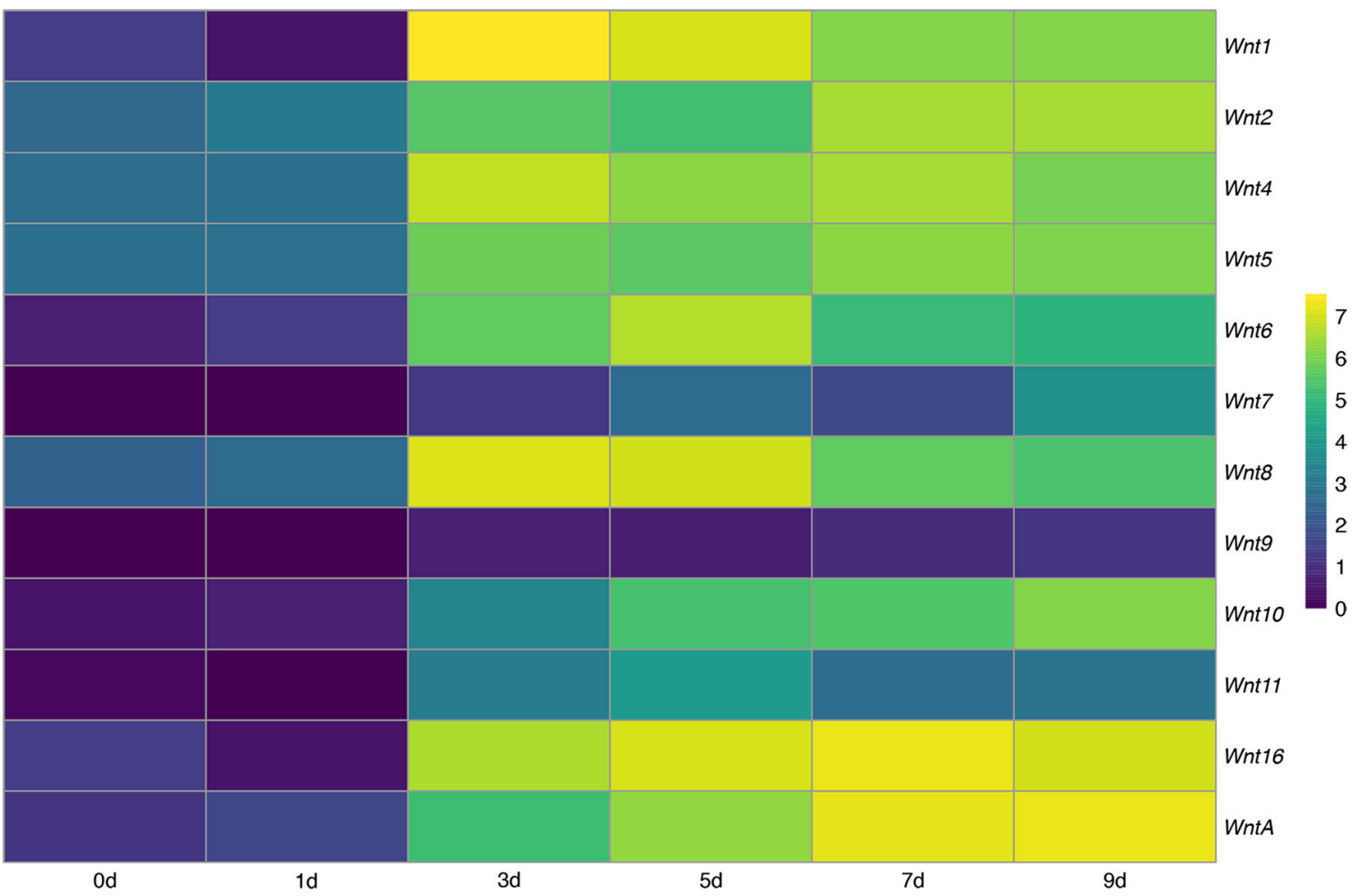

Fig. 3 Expression of Wnt genes during P. caudatus embryogenesis. The estimated counts were averaged between replicates and summed between putative isoforms, and log transformed to visualise the gene-level abundances across developmental stages

we assume lateral expression rather than dorsal and ventral domains).

Wnt6 is expressed in a very specific ectodermal pattern in the posterior of the embryo. Expression is in and around the blastopore. Most significant, however, are the six dot-like expression domains surrounding the blastopore at the edge of a broad region of expression (Fig. 4(C, D)). This expression is similar to that of $F G F 8 / 17 / 18$ in the anterior of the developing embryo (Martín-Durán and Hejnol 2015) and may be correlated with the development of the short and/or long retractor muscles.

Wnt8 is expressed in the form of a single strong posterior domain (Fig. 4(E, F)). However, this domain is restricted to one side of the blastopore opening. Again, owing to the lack of morphological landmarks, we cannot determine if this is dorsal or ventral (we do not assume left-right asymmetric expression).

Wnt10 is expressed in the form of a small domain in the blastopore which is smaller than that of the other posteriorly expressed Wnt genes and is restricted to the blastoporal opening (Fig. $4(\mathrm{G}, \mathrm{H})$ ).

Expression of Wnt16 is surrounding the blastopore in the form of a solid circular and broad domain (Fig. 4(I, J)).

WntA is expressed in the posterior half of the embryo, and thus in a much greater posterior domain as the other Wnt genes (Fig. 4(K, L)). The expression of WntA appears to be stronger in more posterior tissue, while expression towards its anterior border of (detectable) expression is weaker, possibly forming a short-range posterior to anterior gradient (Fig. 4(L)).

\section{Discussion}

\section{Restricted expression of Wnt genes early during priapulid development}

Of the 12 priapulid Wnt genes identified in sequenced transcriptomes, nine are expressed during embryonic development until 9 days after fertilisation (the first larval stage is reached at approximately 10 days after fertilisation (Wennberg et al. 2008)). Of these nine expressed Wnt genes (see Fig. 3), we retrieved reliable whole-mount in situ expression data for seven genes. The only Wnt genes that show expression in the stage-specific RNA-seq time course, and for which we could not obtain any in situ hybridisation signal, are $W n t 2$ and $W n t 5$. One explanation could be that these genes are ubiquitously expressed at a low level. In such a case, it

Fig. 4 Embryonic expression patterns of Priapulus caudatus Wnt genes. In all panels, asterisks mark the posterior pole of the embryo. The first column shows embryos in posterior view (A, E, I, M, Q, U); the second column shows embryos in lateral view (B, F, J, N, R, V); the third column shows schematic expression in lateral view (cf. second column); the fourth column shows schematic expression in posterior-lateral view (the white arrows indicate the AP axis). Roman numerals in panel $\mathrm{E}$ indicate six dot-like expression domains surrounding the posterior pole of the embryo. In all data panels, the developmental stage is indicated. The arrows in panels showing the introvertula stage in lateral viewpoint to the groove separating the introvert from the trunk 

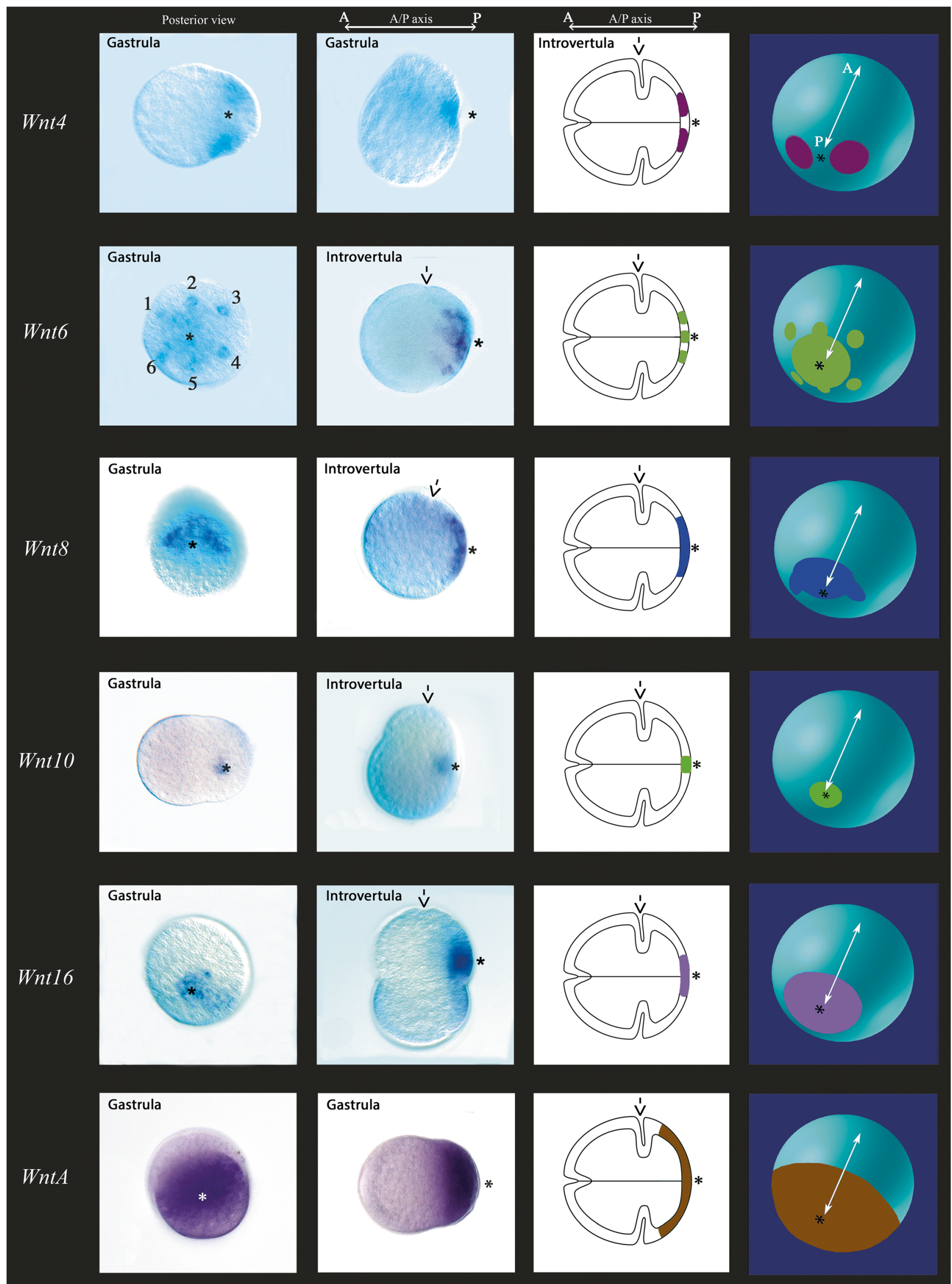
would be difficult to distinguish their expression pattern from background signal, a common problem in Priapulus in situ hybridisation experiments. If these genes are ubiquitously expressed, then the level of expression per cell must be low (cf. level of RNA-seq. signal (Fig. 3)).

\section{Expression of priapulid Wnt genes suggests an evolutionary conserved function of Wnt signalling in posterior patterning and posterior elongation}

Wnt gene signalling appears to be a conserved component of posterior development and posterior elongation as reported from a wide range of metazoans.

Already in sponges like the demosponges Amphimedon and Halisarca, the expression of Wnt genes in posterior tissues indicates a potential role in the establishment of the AP axis during development (Adamska et al. 2007, 2010; Leininger et al. 2014; Borisenko et al. 2016). Similarly, Wnt signalling could be involved in oral/aboral patterning in Ctenophora (Jager et al. 2013, but see Pang et al. 2010). In cnidarians, Wnt signalling is involved in gastrulation and AP axis patterning (e.g. Hobmayer et al. 2000; Kusserow et al. 2005; Lee et al. 2006; Lengfeld et al. 2009). The function of Wnt signalling in posterior elongation and AP axis patterning is well documented in deuterostomes such as vertebrates (e.g. Schier and Talbot 2005) and expression pattern analysis suggests that Wnt signalling is also involved in these processes in other deuterostomes (e.g. Onai et al. 2009; Kawai et al. 2016; Darras et al. 2018). Although there are not much data on lophotrochozoan (spriralian) protostomes, at least in annelids Wnt genes appear to be involved in segmentation and posterior elongation as well (e.g. Janssen et al. 2010; Cho et al. 2010; Gazave et al. 2013).

In ecdysozoans, the other group of protostomian animals, data on Wnt signalling are mainly restricted to arthropods. Here, Wnt signalling and the posterior factors caudal (cad) and even-skipped (eve) interact in gene regulatory networks controlling segment addition and posterior elongation (e.g. Copf et al. 2004, Miyawaki et al. 2004, Shinmyo et al. 2005, Angelini and Kaufman 2005, Bolognesi et al. 2008, McGregor et al. 2008, 2009, Beermann et al. 2011, Chesebro et al. 2013, El-Sherif et al. 2014, Oberhofer et al. 2014, Hayden et al. 2015, Schönauer et al. 2016, Auman et al. 2017, reviewed in Williams and Nagy 2017). Gene expression data in onychophorans suggest that these genes may play a conserved role during onychophoran posterior elongation as well (Eriksson et al. 2009; Janssen and Budd 2013; Hogvall et al. 2014).

Data from non-panarthropod ecdysozoans, however, are scarce, except for the model nematode Caeorhabditis elegans. This species only possesses five Wnt genes (mom-2, lin-44, egl-20, cwn-1 and $c w n-2)$, most of which are expressed and function in posterior structures of the developing larva, or are active in a posterior organisation centre of the embryo that establishes anterior-posterior polarity (e.g. Bischoff and Schnabel 2006; Sawa and Korswagen 2013). The Caenorhabditis caudal ortholog pal-1 is involved in posterior development (Edgar et al. 2001), and so is vab-7, an evenskipped (eve) ortholog (Pocock et al. 2004). Altogether, data on cad, eve and Wnt orthologs imply some sort of conserved function in posterior development in the nematode, at least in comparison with arthropods and onychophorans.

Data on Wnt genes and other factors possibly associated with posterior elongation are not available from other nematodes, nematomorphs or scalidophorans (kinorhynchs, loriciferans and priapulids), except for the expression data on Priapulus wg/Wnt1, cad and eve (Martín-Durán et al. 2012; MartínDurán and Hejnol 2015), and data provided in this study.

Our data demonstrate that several Wnt genes are transcribed in, around or in close proximity to the posteriorly located blastopore. The only Wnt gene with a significantly different expression pattern, WntA is expressed in the complete posterior half of the embryo. These data, together with the previously published expression data on $w g / W n t 1$, eve and cad, strongly suggest a role of Wnt genes (and Wnt signalling) in posterior patterning and posterior elongation in priapulids, likely as part of a similar gene regulatory network as demonstrated for arthropods.

\section{Wnts and border formation}

Wnt signalling appears to play an important role in intrasegmental patterning in segmented animals such as arthropods, onychophorans and annelids (e.g. Janssen et al. 2010; Hogvall et al. 2014). The most famous Wnt gene, wingless $(\mathrm{wg} / \mathrm{Wnt} \mathrm{l})$ is a key factor in maintaining parasegmental boundaries in concert with other segmentpolarity genes (SPGs) in Drosophila (reviewed in Sanson 2001). Similar segmentally reiterated expression patterns of $w g / W n t 1$ orthologs and other SPGs in members in all arthropod clades, onychophorans and annelids suggest that the function of $w g / W n t 1$ in border formation dates back to the last common ancestor of protostomes and deuterostomes (Damen 2002; Prud'homme et al. 2003; Janssen et al. 2004; Eriksson et al. 2009; Dray et al. 2010; Janssen and Budd 2013) and may thus lend support for a segmented last common ancestor (Balavoine and Adoutte 2003; Balavoine 2014). Although relatively little is known about the function of other Wnt genes in intrasegmental patterning and/or border formation, strikingly many Wnt genes are expressed in transverse segmental stripes in and around the (para) segmental boundaries in panarthropods and annelids (Janssen et al. 2010; Janssen and Posnien 2014; Hogvall et al. 2014; Hayden and Arthur 2014; Pruitt et al. 2014; Constantinou et al. 2016). These patterns suggest that Wnt genes may also be involved in the patterning of body units (segments) along the anteriorposterior (AP) body axis and thus border formation (either 
morphological borders such as segmental boundaries, or molecular borders such as the parasegment boundaries). Further, a role of Wnt genes in border formation in non-segmented animals has been recently shown for brachiopod larvae (Vellutini and Hejnol 2016).

Priapulids are not considered "segmented" animals as there are no segmentally repeated body structures, or morphologically visible boundaries except for the boundary between the anterior introvert and the posterior trunk. This boundary is established early during development, as the developing introvert is characterised by much smaller cells than the trunk which is formed from larger cells (Wennberg et al. 2008).

We found that none of the priapulid Wnt genes appears to be expressed at the border between introvert and trunk, at least not in the stages for which in situ hybridisation works in this species. It is possible that formation and maintenance of this morphological border do not require Wnt signalling. Alternatively, Wnt signalling may not be recognised owing to a low level of expression, or Wnt genes are expressed but at different developmental stages for which in situ hybridisation does not work. Additionally, we did not detect any sign of expression that would suggest that the ancestor of priapulids was segmented, such as cryptic expression of Wnt genes in reiterated patterns (transverse stripes) along the AP body axis; a lack that counts against the common origin of segmentation in annelids (Lophotrochozoa) and panarthropods (Ecdysozoa).

Acknowledgements We thank the Sven Lové Centre for Marine Sciences for the help with the collections.

Authors' contributions $\mathrm{MH}$ and $\mathrm{RJ}$ designed the project. $\mathrm{MH}$ conducted most of the experiments. JMMD and BCV did the embryo collections for the stage-specific RNA-seq analyses, and BCV performed the extractions and bioinformatic analyses. All authors discussed the results. RJ wrote the first draft of the manuscript. All authors worked on the final version of the manuscript.

Funding information Financial funding was provided by the Swedish Natural Science Council (VR), grant no. 621-2011-4703, the Sars International Centre for Marine Molecular Biology core budget and the European Union Infrastructures program (ASSEMBLE grant agreement no 227799).

Open Access This article is distributed under the terms of the Creative Commons Attribution 4.0 International License (http:// creativecommons.org/licenses/by/4.0/), which permits unrestricted use, distribution, and reproduction in any medium, provided you give appropriate credit to the original author(s) and the source, provide a link to the Creative Commons license, and indicate if changes were made.

\section{References}

Adamska M, Degnan SM, Green KM, Adamski M, Craigie A, Larroux C, Degnan BM (2007) Wnt and TGF-beta expression in the sponge Amphimedon queenslandica and the origin of metazoan embryonic patterning. PLoS One 2:e1031
Adamska M, Larroux C, Adamski M, Green K, Lovas E, Koop D, Richards GS, Zwafink C, Degnan BM (2010) Structure and expression of conserved Wnt pathway components in the demosponge Amphimedon queenslandica. Evol Dev 12:494-518

Angelini DR, Kaufman TC (2005) Functional analyses in the milkweed bug Oncopeltus fasciatus (Hemiptera) support a role for Wnt signaling in body segmentation but not appendage development. Dev Biol 283:409-423

Aulehla A, Herrmann BG (2004) Segmentation in vertebrates: clock and gradient finally joined. Genes Dev 18:2060-2067

Auman T, Vreede BMI, Weiss A, Hester SD, Williams TA, Nagy LM, Chipman AD (2017) Dynamics of growth zone patterning in the milkweed bug Oncopeltus fasciatus. Development 144:1896-1905

Balavoine G (2014) Segment formation in annelids: patterns, processes and evolution. Int J Dev Biol 58:469-483

Balavoine G, Adoutte A (2003) The segmented urbilateria: a testable scenario. Integr Comp Biol 43:137-147

Beermann A, Prühs R, Lutz R, Schröder R (2011) A context-dependent combination of Wnt receptors controls axis elongation and leg development in a short germ insect. Development. 138:2793-2805

Bischoff M, Schnabel R (2006) A posterior centre establishes and maintains polarity of the Caenorhabditis elegans embryo by a Wntdependent relay mechanism. PLoS Biol 4:e396

Bolognesi R, Farzana L, Fischer TD, Brown SJ (2008) Multiple Wnt genes are required for segmentation in the short-germ embryo of Tribolium castaneum. Curr Biol 18:1624-1629

Borisenko I, Adamski M, Ereskovsky A, Adamska M (2016) Surprisingly rich repertoire of Wnt genes in the demosponge Halisarca dujardini. BMC Evol Biol 16:123-130

Borner J, Rehm P, Schill RO, Ebersberger I, Burmester T (2014) A transcriptome approach to ecdysozoan phylogeny. Mol Phylogenet Evol 80:79-87

Bray NL, Pimentel H, Melsted P, Pachter L (2016) Near-optimal probabilistic RNA-seq quantification. Nat Biotechnol 34:525-527

Campbell LI, Rota-Stabelli O, Edgecombe GD, Marchioro T, Longhorn SJ, Telford MJ, Philippe H, Rebecchi L, Peterson KJ, Pisani D (2011) MicroRNAs and phylogenomics resolve the relationships of Tardigrada and suggest that velvet worms are the sister group of Arthropoda. Proc Natl Acad Sci U S A 108:15920-15924

Chawengsaksophak K, de Graaff W, Rossant J, Deschamps J, Beck F (2004) Cdx2is essential for axial elongation in mouse development. Proc Natl Acad Sci U S A 101:7641-7645

Chesebro JE, Pueyo JI, Couso JP (2013) Interplay between a Wntdependent organiser and the Notch segmentation clock regulates posterior development in Periplaneta americana. Biol Open 2: 227-237

Cho SJ, Vallès Y, Giani VC Jr, Seaver EC, Weisblat DA (2010) Evolutionary dynamics of the wnt gene family: a lophotrochozoan perspective. Mol Biol Evol 27:1645-1658

Constantinou SJ, Pace RM, Stangl AJ, Nagy LM, Williams TA (2016) Wnt repertoire and developmental expression patterns in the crustacean Thamnocephalus platyurus. Evol Dev 18:324-341

Copf T, Schröder R, Averof M (2004) Ancestral role of caudal genes in axis elongation and segmentation. Proc Natl Acad Sci U S A 101: 17711-17715

Croce JC, McClay DR (2008) Evolution of the Wnt pathways. Methods Mol Biol 469:3-18

Damen WGM (2002) Parasegmental organization of the spider embryo implies that the parasegment is an evolutionary conserved entity in arthropod embryogenesis. Development 129:1239-1250

Darras S, Fritzenwanker JH, Uhlinger KR, Farrelly E, Pani AM, Hurley IA, Norris RP, Osovitz M, Terasaki M, Wu M, Aronowicz J, Kirschner M, Gerhart JC, Lowe CJ (2018) Anteroposterior axis patterning by early canonical Wnt signaling during hemichordate development. PLoS Biol 16:e2003698 
de Rosa R, Prud'homme B, Balavoine G (2005) Caudal and even-skipped in the annelid Platynereis dumerilii and the ancestry of posterior growth. Evol Dev 7:574-587

Dray N, Tessmar-Raible K, Le Gouar M, Vibert L, Christodoulou F, Schipany K, Guillou A, Zantke J, Snyman H, Béhague J, Vervoort M, Arendt D, Balavoine G (2010) Hedgehog signaling regulates segment formation in the annelid Platynereis. Science. 20329: 339-342

Edgar LG, Carr S, Wang H, Wood WB (2001) Zygotic expression of the caudal homolog pal-1 is required for posterior patterning in Caenorhabditis elegans embryogenesis. Dev Biol 229:71-88

El-Sherif E, Zhu X, Fu J, Brown SJ (2014) Caudal regulates the spatiotemporal dynamics of pair-rule waves in Tribolium. PLoS Genet 10: e1004677

Eriksson BJ, Tait NN, Budd GE, Akam M (2009) The involvement of engrailed and wingless during segmentation in the onychophoran Euperipatoides kanangrensis (Peripatopsidae: Onychophora) (Reid 1996). Dev Genes Evol 219:249-264

Gabriel WN, Goldstein B (2007) Segmental expression of Pax3/7 and engrailed homologs in tardigrade development. Dev Genes Evol 217:421-433

Gazave E, Béhague J, Laplane L, Guillou A, Préau L, Demilly A, Balavoine G, Vervoort M (2013) Posterior elongation in the annelid Platynereis dumerilii involves stem cells molecularly related to primordial germ cells. Dev Biol 382:246-267

Giribet G, Edgecombe GD (2017) Current understanding of Ecdysozoa and its internal phylogenetic relationships. Integr Comp Biol 57: 455-466

Gouy M, Guindon S, Gascuel O (2010) SeaView version 4: a multiplatform graphical user interface for sequence alignment and phylogenetic tree building. Mol Biol Evol 27:221-224

Hayden L, Arthur W (2014) The centipede Strigamia maritima possesses a large complement of Wnt genes with diverse expression patterns. Evol Dev 16:127-138

Hayden L, Schlosser G, Arthur W (2015) Functional analysis of centipede development supports roles for Wnt genes in posterior development and segment generation. Evol Dev 17:49-62

Hobmayer B, Rentzsch F, Kuhn K, Happel CM, von Laue CC, Snyder P, Rothbächer U, Holstein TW (2000) WNT signalling molecules act in axis formation in the diploblastic metazoan Hydra. Nature 407: 186-189

Hogvall M, Schönauer A, Budd GE, McGregor AP, Posnien N, Janssen R (2014) Analysis of the Wnt gene repertoire in an onychophoran provides new insights into the evolution of segmentation. Evodevo $5: 14$

Huelsenbeck JP, Ronquist F (2001) MRBAYES: Bayesian inference of phylogenetic trees. Bioinformatics 17:754-755

Jager M, Dayraud C, Mialot A, Quéinnec E, le Guyader H, Manuel M (2013) Evidence for involvement of Wnt signalling in body polarities, cell proliferation, and the neuro-sensory system in an adult ctenophore. PLoS One 8:e84363

Janssen R, Budd GE (2013) Deciphering the onychophoran 'segmentation gene cascade': gene expression reveals limited involvement of pair rule gene orthologs in segmentation, but a highly conserved segment polarity gene network. Dev Biol 382:224-234

Janssen R, Posnien N (2014) Identification and embryonic expression of Wnt2, Wnt4, Wnt5 and Wnt9 in the millipede Glomeris marginata (Myriapoda: Diplopoda). Gene Expr Patterns 14:55-61

Janssen R, Prpic NM, Damen WG (2004) Gene expression suggests decoupled dorsal and ventral segmentation in the millipede Glomeris marginata (Myriapoda: Diplopoda). Dev Biol 268:89104

Janssen R, Le Gouar M, Pechmann M, Poulin F, Bolognesi R, Schwager EE, Hopfen C, Colbourne JK, Budd GE, Brown SJ, Prpic NM, Kosiol C, Vervoort M, Damen WG, Balavoine G, McGregor AP (2010) Conservation, loss, and redeployment of Wnt ligands in protostomes: implications for understanding the evolution of segment formation. BMC Evol Biol 10:374

Kawai N, Kuraishi R, Kaneko H (2016) Wnt, Frizzled, and sFRP gene expression patterns during gastrulation in the starfish Patiria (Asterina) pectinifera. Gene Expr Patterns 21:19-27

Kusserow A, Pang K, Sturm C, Hrouda M, Lentfer J, Schmidt HA, Technau U, von Haeseler A, Hobmayer B, Martindale MQ, Holstein TW (2005) Unexpected complexity of the Wnt gene family in a sea anemone. Nature 433:156-160

Laumer CE, Bekkouche N, Kerbl A, Goetz F, Neves RC, Sørensen MV, Kristensen RM, Hejnol A, Dunn CW, Giribet G, Worsaae K (2015) Spiralian phylogeny informs the evolution of microscopic lineages. Curr Biol 25:2000-2006

Leclère L, Bause M, Sinigaglia C, Steger J, Rentzsch F (2016) Development of the aboral domain in Nematostella requires $\beta$ catenin and the opposing activities of Six $3 / 6$ and Frizzled5/8. Development 143:1766-1777

Lee PN, Pang K, Matus DQ, Martindale MQ (2006) A WNT of things to come: evolution of Wnt signaling and polarity in cnidarians. Semin Cell Dev Biol 17:157-167

Leininger S, Adamski M, Bergum B, Guder C, Liu J, Laplante M, Bråte J, Hoffmann F, Fortunato S, Jordal S, Rapp HT, Adamska M (2014) Developmental gene expression provides clues to relationships between sponge and eumetazoan body plans. Nat Commun 5:3905

Lengfeld T, Watanabe H, Simakov O, Lindgens D, Gee L, Law L, Schmidt HA, Ozbek S, Bode H, Holstein TW (2009) Multiple Wnts are involved in Hydra organizer formation and regeneration. Dev Biol 330:186-199

Logan CY, Nusse R (2004) The Wnt signaling pathway in development and disease. Annu Rev Cell Dev Biol 20:781-810

Martín-Durán JM, Hejnol A (2015) The study of Priapulus caudatus reveals conserved molecular patterning underlying different gut morphogenesis in the Ecdysozoa. BMC Biol 13:29

Martín-Durán JM, Janssen R, Wennberg S, Budd GE, Hejnol A (2012) Deuterostomic development in the protostome Priapulus caudatus. Curr Biol 22:2161-2166

McGregor AP, Pechmann M, Schwager EE, Feitosa NM, Kruck S, Aranda M, Damen WG (2008) Wnt8 is required for growth-zone establishment and development of opisthosomal segments in a spider. Curr Biol 18:1619-1623

McGregor AP, Pechmann M, Schwager EE, Damen WG (2009) An ancestral regulatory network for posterior development in arthropods. Commun Integr Biol 2:174-176

McIntyre DC, Seay NW, Croce JC, McClay DR (2013) Short-range Wnt5 signaling initiates specification of sea urchin posterior ectoderm. Development 140:4881-4889

Miyawaki K, Mito T, Sarashina I, Zhang H, Shinmyo Y, Ohuchi H, Noji S (2004) Involvement of Wingless/Armadillo signaling in the posterior sequential segmentation in the cricket, Gryllus bimaculatus (Orthoptera), as revealed by RNAi analysis. Mech Dev 121:119 130

Murat S, Hopfen C, McGregor AP (2010) The function and evolution of Wnt genes in arthropods. Arthropod Struct Dev 39:446-452

Nielsen C (2012) Animal evolution: interrelationships of the living phyla, 3rd edn. Oxford University Press, Oxford

Notredame C, Higgins DG, Heringa J (2000) T-Coffee: a novel method for fast and accurate multiple sequence alignment. J Mol Biol 302: 205-217

Oberhofer G, Grossmann D, Siemanowski JL, Beissbarth T, Bucher G (2014) Wnt/ $\beta$-catenin signaling integrates patterning and metabolism of the insect growth zone. Development. 141:4740-4750

Onai T, Lin HC, Schubert M, Koop D, Osborne PW, Alvarez S, Alvarez R, Holland ND, Holland LZ (2009) Retinoic acid and Wnt/betacatenin have complementary roles in anterior/posterior patterning embryos of the basal chordate amphioxus. Dev Biol 332:223-233 
Pang K, Ryan JF, Comparative Sequencing Program NISC, Mullikin JC, Baxevanis AD, Martindale MQ (2010) Genomic insights into Wnt signaling in an early diverging metazoan, the ctenophore Mnemiopsis leidyi. Evodevo 1:10

Pocock R, Ahringer J, Mitsch M, Maxwell S, Woollard A (2004) A regulatory network of T-box genes and the even-skipped homologue vab-7 controls patterning and morphogenesis in C. elegans. Development 131:2373-2385

Prud'homme B, de Rosa R, Arendt D, Julien JF, Pajaziti R, Dorresteijn AW, Adoutte A, Wittbrodt J, Balavoine G (2003) Arthropod-like expression patterns of engrailed and wingless in the annelid Platynereis dumerilii suggest a role in segment formation. Curr Biol 13:1876-1881

Pruitt MM, Letcher EJ, Chou HC, Bastin BR, Schneider SQ (2014) Expression of the wnt gene complement in a spiral-cleaving embryo and trochophore larva. Int J Dev Biol 58:563-573

Sanson B (2001) Generating patterns from fields of cells: examples from Drosophila segmentation. EMBO Rep 2:1083-1088

Sawa H, Korswagen HC (2013) Wnt signaling in C. elegans. In: WormBook, pp 1-30

Schier AF, Talbot WS (2005) Molecular genetics of axis formation in zebrafish. Annu Rev Genet 39:561-613

Schmidt-Rhaesa A (1998) The position of the Arthropoda in the phylogenetic system. J Morphol 238:263-285

Schönauer A, Paese CL, Hilbrant M, Leite DJ, Schwager EE, Feitosa NM, Eibner C, Damen WG, McGregor AP (2016) The Wnt and Delta-Notch signalling pathways interact to direct pair-rule gene expression via caudal during segment addition in the spider Parasteatoda tepidariorum. Development 143:2455-2463

Scimone ML, Cote LE, Rogers T, Reddien PW (2016) Two FGFRL-Wnt circuits organize the planarian anteroposterior axis. Elife 5:e12845
Shimizu T, Bae YK, Muraoka O, Hibi M (2005) Interaction of Wnt and caudal-related genes in zebrafish posterior body formation. Dev Biol 279:125-141

Shinmyo Y, Mito T, Matsushita T, Sarashina I, Miyawaki K, Ohuchi H, Noji S (2005) Caudal is required for gnathal and thoracic patterning and for posterior elongation in the intermediate-germband cricket Gryllus bimaculatus. Mech Dev 122:231-239

Vellutini BC, Hejnol A (2016) Expression of segment polarity genes in brachiopods supports a non-segmental ancestral role of engrailed for bilaterians. Sci Rep 6:32387

Wennberg SA, Janssen R, Budd GE (2008) Early embryonic development of the priapulid worm Priapulus caudatus. Evol Dev 10:326338

Wennberg S, Janssen R, Budd GE (2009) Hatching and earliest larval stages of the priapulid worm Priapulus caudatus. Inv Biol 128:157171

Wiese KE, Nusse R, van Amerongen R (2018) Wnt signalling: conquering complexity. Development. 145:dev165902. https://doi.org/10. 1242/dev. 165902

Williams TA, Nagy LM (2017) Linking gene regulation to cell behaviors in the posterior growth zone of sequentially segmenting arthropods. Arthropod Struct Dev 46:380-394

Yazawa S, Umesono Y, Hayashi T, Tarui H, Agata K (2009) Planarian Hedgehog/Patched establishes anterior-posterior polarity by regulating Wnt signaling. Proc Natl Acad Sci U S A 106:22329-22334

Publisher's note Springer Nature remains neutral with regard to jurisdictional claims in published maps and institutional affiliations. 